\title{
Hipnoterapi Dengan Part Therapy Untuk Penurunan Perilaku Merokok
}

\author{
Giyati, ${ }^{1}$ Kamsih Astuti, ${ }^{2}$ Siti Noor Fatmah L, ${ }^{2}$ \\ gie.wakidi@gmail.com \\ ${ }^{1}$ Mahasiswa Magister Psikologi Profesi Universitas Mercu Buana Yogyakarta \\ ${ }^{2}$ Dosen Fakultas Psikologi, Universitas Mercu Buana Yogyakarta
}

\begin{abstract}
Smoking becomes big problems in the society. A smoker finds some difficulties in trying to quit smoking. This is because of the inner conflicts between making decision of quitting or continuing smoking. Therefore, it is necessary to look for interventions to solve these problems. This study aims to determine the effect of hypnotherapy with part therapy to decrease smoking behavior. This study was conducted on 2 smokers. The research design is single case experiment design with A-B-A-B-A design. Data analysis used simple descriptive test by presenting data using graph and histogram. The results showed that there are some differences in smoking behavior before and after intervention. The intention of smoking of MFH before intervention is more than 15 cigarettes per day (weight category) becomes medium category (4-15 sticks per day) after the interventions. Whereas, the NK before the interventions that is in medium category (4-15 cigarettes per day) becomes mild category (1-4 stems per day) after the intervention of smoking places. The places that are commonly used by MFH are private rooms, campus and food stalls, while NK used food stalls as the place to smoke. The smoking situation for MFH and NK is when they are hanging out with friends. The functions of smoking for MFH are for adding pleasure, pleasing feeling, and reducing anger and anxiety while the function of smoking for NK is for adding pleasure. After doing hypnotherapy with part therapy, the intention of smoking, smoking place, smoking situation and the function of smoking has decreased. However, in those factors the subject still do smoking behavior but in light intention. The physical and psychological changes after intervention of MFH are the subjects feel freshness and good breathing. MFH had self-awareness, more strong desire, and more healthy life with new pattern to stop smoking, while NK becomes fresher, good feeling, happy, and breathe smoothly, can refuse a friend's invitation to smoke, and has more to strength to quit smoking. Based on the research results, it can be concluded that there is influence of hypnotherapy with part therapy in decreasing smoking behavior. Smoking behavior after intervention was lower than before intervention.
\end{abstract}

Keywords: Hypnotherapy, part therapy, smoking behavior

\begin{abstract}
Abstrak
Merokok menjadi permasalahan rumit dalam kehidupan masyarakat. Seorang perokok mencoba mengurangi atau berhenti merokok merasakan kesulitan untuk upaya tersebut. Hal ini karena adanya pertentangan batin terkait dengan alasan-alasan antara berhenti merokok atau tetap merokok. Oleh sebab itu, perlu kiranya dicarikan intervensi yang dapat menjadi alternatif untuk upaya tersebut. Penelitian ini bertujuan untuk mengetahui pengaruh hipnoterapi dengan part therapy untuk penurunan perilaku merokok. Penelitian ini dilakukan terhadap 2 orang perokok. Rancangan yang digunakan single case experiment design dengan desain A-B-A-B-A. Analisis data menggunakan uji deskriptif sederhana dengan menyajikan data menggunakan grafik dan histogram. Hasil penelitian menunjukkan ada perbedaan perilaku merokok sebelum dan sesudah intervensi. Intensi perokok sebelum intervensi pada MFH kategori berat (lebih 15 batang/hari) dibanding setelah intervensi kategori sedang (4-15 batang/hari), sedangkan untuk NK sebelum
\end{abstract}


intervensi kategori sedang (4-15 batang/hari) dibanding setelah intervensi kategori ringan (1-4 batang/hari). Tempat merokok yang sering digunakan MFH: kamar pribadi, kampus dan warung makan, sedangkan NK: warung makan. Situasi merokok untuk MFH maupun NK yaitu saat berkumpul dengan teman, sedangkan untuk fungsi merokok MFH: menambah kenikmatan, menyenangkan perasaan, dan mengurangi rasa cemas, marah dan gelisah, sedangkan NK: menambah kenikmatan. Setelah dilakukan hipnoterapi dengan part therapy baik intensi merokok, tempat merokok, situasi merokok dan fungsi merokok mengalami penurunan, walaupun pada faktor-faktor tersebut subjek masih melakukan perilaku merokoknya, namun dalam intensi ringan. Perubahan secara fisik maupun psikis setelah intervensi MFH: merasakan fresh dan pernafasannya plong, serasa menghilangkan batu yang ada di dada, sudah ada kesadaran diri, lebih mempunyai keinginan kuat, dan lebih menata hidup sehat dengan pola baru untuk berhenti merokok, sedangkan NK: ada perasaan segar, badan terasa enak, senang, dan nafas lancar, serta sudah dapat menolak ajakan teman untuk merokok, dan lebih dapat menguatkan niatnya untuk berhenti merokok. Berdasarkan hasil penelitian dapat disimpulkan bahwa ada pengaruh hipnoterapi dengan part therapy untuk penurunan perilaku merokok. Perilaku merokok setelah intervensi lebih rendah dibandingkan sebelum intervensi.

Kata kunci: Hipnoterapi, part therapy, perilaku merokok

\section{PENDAHULUAN}

Permasalahan rokok masih menjadi pekerjaan rumah Bangsa Indonesia. Hal ini karena dampak yang ditimbulkan dari perilaku merokok baik bagi kesehatan, ekonomi, dan sosial perokok maupun masyarakat di sekitarnya. Bagi keseha-tan, dijelaskan dalam UU No. 36/2009 tentang Kesehatan, Pasal 13 ayat 1 sam-pai 3, bahwa tembakau dinyatakan seba-gai zat adiktif sehingga perlu dilakukan pengamanan agar tidak mengganggu dan membahayakan kesehatan perorangan, keluarga, masyarakat, dan lingkungan. Apabila zat adiktif ini diproduksi, diedar-kan, dan digunakan harus memenuhi standar dan/atau persyaratan yang ditetapkan. Dampak ekonomi, dijelaskan dalam penelitian Fawzani \& Triratnawati (2005), bahwa terdapat $60 \%$ dari perokok aktif $(84,84$ juta orang dari 141,44 juta) orang berasal dari penduduk miskin atau ekono-mi lemah yang sehari-harinya kesulitan dalam memenuhi kebutuhan pokoknya. Data dari TCSC (2013) melaporkan bah-wa pada rumah tangga termiskin, kon-sumsi tembakau dan sirih menempati proporsi pengeluaran terbesar kedua setelah konsumsi padi-padian (11,7\%). Rokok mengalahkan kebutuhan gizi lebih dari 17 kali pengeluaran daging, lebih 5 kali pengeluaran susu dan telur, lebih 2 kali masing-masing pengeluaran ikan dan pengeluaran untuk sayuran, serta lebih dari 9 kali pengeluaran untuk buah.

Dampak sosial, mengacu pada pe-nelitian Rochmayani (2008) melaporkan bahwa perilaku merokok tidak hanya ber-dampak negatif pada diri pribadi perokok, namun berdampak juga pada aspek sosial seperti keluarga, teman dan rekan kerja. Salah satu contoh dampak rokok terhadap kehidupan sosial dapat dilihat dari ketidaknyamanan dan dampak kesehatan bagi perokok pasif akibat paparan asap rokok.

Perilaku merokok adalah kesena-ngan oral (mulut) dengan memasukkan bahan yang berasal dari dedaunan (tem-bakau) yang mengandung zat tertentu (khususnya nikotin) dengan cara meng-hisap dan menghembuskannya sebagai tindakan untuk memperoleh kenikmatan (Uthaq \& Kumolohadi, 2008). Faktorfaktor perilaku merokok antara lain adalah: (1) Intensi merokok, seberapa sering individu melakukan aktivitas merokok. (2) Tempat merokok, tempat individu melakukan aktivitas merokok. (3) Situasi merokok yaitu perilaku merokok dipengaruhi oleh keadaan yang dialami-nya pada saat itu. 4) Fungsi merokok, seberapa penting aktivitas merokok bagi seorang individu dalam kehidupan sehari-hari (Komalasari \& Helmi, 2000).

Sumber stressor yang sering terjadi pada seorang perokok adalah rasa takut, cemas dan kompulsif dalam menjalani permasalahan hidupnya. Awal mula sese-orang merokok adalah untuk menenang-kan dan mendinginkan permasalahan hi-dupnya. Namun setelah menjadi perokok, ada kebimbangan antara berhenti atau melanjutkan perilaku merokok (tahap initiation), hal ini disebabkan karena terjadinya disonansi kognitif dalam diri seorang perokok. Di satu sisi seorang perokok meyakini bahwa merokok dapat menyebabkan rileks, menjernihkan piki-ran, membuat bahagia, membuat tenang dan sebagainya (Gibson \& Benthin dalam 
Thomas \& Suci, 2010), namun disisi lain seorang perokok juga memahami dan meyakini risiko yang timbul dari perilaku merokok baik dari segi kesehatan (me-nyebabkan penyakit paru-paru, kanker, jantung, gangguan janin dan sebagainya) maupun dari segi sosial ekonomi (dapat menghabiskan uang, polusi udara, aktivitas sosial terganggu dan sebagai-nya) baik bagi diri sendiri maupun bagi orang lain di sekitarnya. Ketidaksesuaian apa yang dipikirkan (area sadar) oleh seorang perokok akan menimbulkan ketidaknyamanan secara psikologis (Eliot \& Devine, dalam Allahyani, 2012), se-hingga perokok termotivasi untuk melaku-kan upaya mengurangi atau menghen-tikan perilakunya.

Keberhasilan perokok dalam upaya berhenti merokok pada individu satu dengan lainnya ada perbedaan, hal ini tergantung dari penyebab awal merokok, rentang waktu menjadi perokok, dosis rokok yang dihisap, dan kuatnya gejolak yang dialami. Meskipun telah memiliki keinginan berhenti merokok bukanlah hal mudah, terutama bagi perokok berat yang mempunyai rentang waktu merokok lama dan dosis tinggi. Oleh karena itu, dibutuh-kan suatu usaha yang lebih keras untuk dapat berhenti merokok (Syafie, 2009). Selain itu, secara psikis perokok yang sudah terbiasa sering mengambil batang rokok dan korek api dari dalam sakunya, maka ketika perokok meninggalkan kebiasaan itu akan merasa ada sesuatu yang hilang dalam hidupnya. Hal ini juga menjadi salah satu sebab semakin sulit-nya meninggalkan kebiasaan merokok-nya. Oleh karena itu keberhasilan ber-henti merokok dapat diprediksi melalui faktor frekuensi merokoknya (Abdullah dkk., 2014).

Walaupun sulit untuk menghentikan perilaku merokok, namun masih ada upaya yang dapat dilakukan untuk perubahan perilaku tersebut. Salah satu upaya yang dapat dilakukan adalah penggunaan hipnoterapi dengan part therapy. Menurut Hakim (2010), hipno-terapi dengan pendekatan part therapy cocok digunakan untuk kasus-kasus yang berkaitan dengan adanya pertentangan atau kebimbangan dalam diri klien dalam upaya berhenti merokok. Adapun menurut IACH (2015), pendekatan part therapy digunakan untuk masalah dengan konflik internal yang terjadi dalam diri seseorang karena terdapatnya sisi-sisi kepribadian yang saling bertolak belakang. Kedua sisi tersebut memiliki tujuan "baik" menurut sudut pandang masing-masing bagian (part), sehingga menimbulkan perten-tangan yang terus menerus. Untuk memenangkan salah satu bagian tersebut perlu pelemahan salah satu bagian, sehingga dapat membantu seseorang untuk mencapai langkah yang diinginkan. Melalui tahapan-tahapan hipnote-rapi dengan part therapy dapat dilihat pengaruhnya terhadap penurunan peri-laku merokok. Tahapan-tahapan yang mengacu pada penelitian Hunter (2015), yang terdiri dari 11 tahapan menjadi satu kesatuan yang dapat memfasilitasi terjadi perubahan perilaku merokok. Pendekatan part therapy merujuk pada pendekatan client centered yaitu pendekatan yang berpusat pada klien. Menurut Durbin (2001) pendekatan yang berpusat pada klien mempunyai tujuan memberdayakan klien, hal ini karena penyebab dan penyelesaian masalah berasal dari pikiran bawah sadar klien, bukan dari pikiran fasilitator. Pada hipnoterapi dengan part therapy, seorang fasilitator hanya dapat memberitahu apa yang harus dilakukan lewat bentuk saran hipnotis, sedangkan kekuatan keputusan ada pada klien. Klien menemukan resolusi terbaik dengan menjawab pertanyaan yang diajukan oleh fasilitator pada waktu yang tepat. Bawah sadar tampaknya mengandung kebijak-sanaan mendalam yang seringkali mengejutkan bagi klien dan terapi, karena bagian dari bawah sadar mengamati hal-hal yang terjadi bahkan selama masa trance.

Bukti keberhasilan hipnoterapi dengan part therapy untuk penurunan perilaku merokok dapat dijelaskan dalam salah satu contoh penanganan kasus perilaku merokok oleh Hunter tahun 2015. Pada penanganan kasus tersebut Hunter terlebih dahulu menggunakan hipnoterapi dengan pendekatan manfaat untuk penurunan perilaku merokok. Namun pende-katan manfaat ini dirasakan gagal, se-hingga digunakanlah pendekatan lain yaitu pendekatan part therapy, hal ini karena perokok mempunyai bagian-bagian yang terpecah karena kebim-bingan atau pertentangan dalam dirinya.

Perilaku merokok merupakan suatu kebiasaan yang dapat dirubah, hal ini dapat terjadi apabila seorang perokok mempunyai keinginan dan keyakinan untuk berhenti atau mengurangi perilaku merokoknya. Upaya yang dapat dilakukan untuk berhenti dan mengurangi perilaku merokok adalah menggunakan hipno-terapi dengan pendekatan part therapy. Pendekatan hipnoterapi dengan part therapy dipilih karena penggunaan hipno-terapi diyakini mempunyai keefektifan antara 0-75\% (Elkins \& Rajab, 2004; Abbot dkk, 2006). Bukti lainnya ditunjuk-kan dari kasus merokok yang ditangani Hunter (2015), bahwa klien pada tahap pelisanan 
memutuskan sekaranglah saat-nya mengambil keputusan sendiri, bukan diatur oleh kebiasaan merokoknya, dan pada kasus lainnya, klien dapat menjauh-kan rokok dari jangkauan tangan se-hingga klien dapat mengambil keputusan secara sadar sebelum menyalakannya.

Merubah persepsi dan keyakinan tentang rokok dapat mengurangi perilaku merokok. Untuk melihat fenomena peri-laku merokok pada perokok di wilayah kota Yogyakarta dengan metode hipnote-rapi yang efektif dengan cara menanam-kan sugesti positif untuk melahirkan se-buah perilaku baru, maka peneliti bermak-sud melakukan sebuah penelitian eks-perimen tentang hipnoterapi dengan part therapy untuk penurunan perilaku mero-kok. Untuk itu, peneliti merumuskan per-masalahan: "Adakah pengaruh hipnoterapi dengan part therapy untuk penurunan perilaku merokok?". Adapun tujuan dari penelitian adalah untuk mengetahui hipnoterapi dengan part therapy untuk penurunan perilaku merokok.

\section{METODE PENELITIAN}

Penelitian ini menggunakan ran-cangan single case experiment design, hal ini karena penelitian lebih memfokus-kan pada pemeriksaan terhadap peru-bahan perilaku merokok pada seorang individu atau paling banyak beberapa orang individu. Perubahan perilaku individu atau sekelompok kecil individu dipantau dan dicatat mingguan, sehari-hari, atau bahkan lebih sering yaitu setiap waktu. Perubahan perilaku individu diban-dingkan dengan dirinya sendiri. Signifi-kansi dalam rancangan Single Subject Research (SSR) bagi seorang individu dilihat dari segi klinis daripada signifikansi statistik. Peneliti menggunakan grafik untuk menunjukkan efek dari intervensi. Selama tahap ini peneliti mencatat perilaku merokok subjek sebelum dan sesudah mendapatkan intervensi. Peneliti mengukur frekuensi target dalam satuan hari (Fraenkel \& Wallen, 2006). Untuk mengetahui perubahan perilaku individu atau sekelompok kecil individu dalam pe-nelitian eksperimen ini menggunakan pola rancangan A-B-A-B-A. Alasan lain yang mendasari pemakaian desain ini ialah karena ingin melihat kondisi tiap subjek (Latipun, 2002; Sunanto, dkk, (2005).

Variabel-variabel dalam penelitian ini antara lain adalah:

1. Variabel terikat: perilaku merokok

Suatu kegiatan atau aktivitas mem-bakar rokok, kemudian menghisap dan menghembuskannya keluar, serta da-pat menimbulkan asap yang dapat ter-hisap oleh diri sendiri maupun orang-orang di sekitarnya. Faktor-faktor peri-laku merokok antara lain: intensi mero-kok, tempat merokok, situasi merokok, dan fungsi merokok dalam kehidupan sehari-hari (Aritonang, 1997; Poerwa-darminta dalam Perwitasari, 2006; Komalasari \& Helmi, 2000). Pengu-kuran perilaku merokok menggunakan frekuensi. Jenis pengukuran ini digu-nakan karena perilaku yang diukur dapat terjadi dalam jumlah tak terbatas dan telah ditentukan waktu pengu-kuran yaitu selama 24 jam (Sunanto dkk. 2005)

Tinggi rendahnya perilaku merokok dapat dilihat berdasarkan jumlah rokok yang dihisap/perhari dari hasil peng-isian behavior checklist perilaku mero-kok. Semakin banyak jumlah rokok yang dihisap/perhari yang diperoleh berarti memungkinkan semakin tinggi perilaku merokok, sedangkan semakin sedikit jumlah rokok yang dihisap/ perhari memungkinkan semakin ren-dah perilaku merokok.

2. Variabel bebas: Hipnoterapi dengan part therapy adalah suatu terapi yang menggunakan metode hipnosis dengan pendekatan part therapy yang dilakukan dengan proses penurunan kesadaran dan peningkatan suges-tibilitas menggunakan cara berkomuni-kasi, negosiasi dan memediasi ter-hadap bagian-bagian atau part yang mengalami pertentangan atau menga-lami kebimbangan dalam diri sese-orang yang dilakukan oleh hipnote-rapist yang dimanfaatkan untuk proses perubahan atau penyembuhan. Taha-pan hipnoterapi dengan part therapy adalah pra-induksi, induksi, pengujian trance hipnosis, sugesti (part therapy), post hypnotic suggestion dan termi-nation. Negosiasi dan mediasi yang dilakukan hipnoterapis dalam Part therapy antara lain: (1) mengidentifikasi dua atau lebih bagian yang berten-tangan; (2) mengenalkan kepada klien tentang bagian yang akan dipisahkan; (3) membimbing klien dan mengekspresikan setiap bagian; (4) mela-kukan mediasi terhadap setiap bagian; (5) meminta kedua bagian untuk ber-sepakat; (6) meminta kedua bagian untuk bersatu dan selaras; dan (7) mengekspresikan hasil akhir dari ba-gian yang telah menyatu, sehingga hasil ini sebagai pilihan klien sendiri. Seluruh tahapan dalam hipnoterapi ini bersumber dari Hakim (2010) dan Hunter (2015). 
Penelitian dilakukan terhadap 2 pe-rokok. Screnning terhadap subjek peneli-tian menggunakan Skala Perilaku Mero-kok, dengan kriteria subjek: (1) Perokok aktif dan ada keinginan untuk mengurangi atau berhenti merokok; dan (2) Mencapai hipnosis pada kondisi medium trance berdasarkan tes sugestibilitas. Pengumpulan data menggunakan metode wawancara, Skala Perilaku Mero-kok dan behavioral checklist perilaku merokok. Hasil uji reliabilitas Skala Peri-laku Merokok berdasarkan nilai koefisien Cronbach's Alpha $(0,896)$. Hasil uji validi-tas Skala Perilaku Merokok berdasarkan nilai korelasi bergerak antara 0,3180,691. Uji coba modul terapi dan alat ukur behavioral checklist perilaku merokok dilakukan melalui proses professional judgement. Pengukuran perilaku merokok dalam behavioral checklist didasarkan pa-da faktorfaktor perilaku merokok berikut:

\begin{tabular}{|l|l|l|}
\hline \multicolumn{1}{|c|}{ Indikator } & Point check-list & \multicolumn{1}{c|}{$\begin{array}{c}\text { Banyak/total (dalam } \\
\text { sehari) }\end{array}$} \\
\hline INTENSI MEROKOK & & \\
\hline 1 sampai 4 batang & & \\
\hline 4 sampai 15 batang & & \\
\hline Lebih dari 15 batang & & \\
\hline TEMPAT MEROKOK & & \\
\hline $\begin{array}{l}\text { Smoking area (bersama orang-orang yang } \\
\text { merokok) }\end{array}$ & & \\
\hline Kamar pribadi/kamar tidur/ rumah & & \\
\hline Restaurant/warung makan/ cafe & & \\
\hline Stasiun & & \\
\hline Kendaraan umum & & \\
\hline Rumah sakit & & \\
\hline Dalam toilet / kamar mandi & & \\
\hline Kampus / tempat kerja & & \\
\hline SITUASI MEROKOK & & \\
\hline Saat dimarahi oleh seseorang & & \\
\hline Saat berkumpul dengan teman & & \\
\hline Cuaca dingin & & \\
\hline $\begin{array}{l}\text { Merokok di semua situasi dan dipengaruhi } \\
\text { oleh ke-adaan }\end{array}$ & & \\
\hline FUNGSI MEROKOK & & \\
\hline Menyenangkan perasaan & & \\
\hline Menambah kenikmatan & & \\
\hline Mengurangi rasa cemas, marah, gelisah & & \\
\hline Kebiasaan & & \\
\hline Sudah ketagihan & & \\
\hline
\end{tabular}

Analisis data menggunakan anali-sis deskriptif sederhana dengan teknik visual inspection untuk mengetahui frekuensi penurunan perilaku merokok. Penggunaaan analisis deskriptif seder-hana dengan teknik visual inspection karena fokus data ditujukan untuk data individu daripada kelompok. Komponen analisis data antara lain: penurunan peri-laku merokok yang diukur berdasarkan intensi merokok (batang/hari), tempat merokok (berapa batang rokok yang dihisap di tempat tersebut), situasi merokok (berapa batang rokok yang 
dihisap pada situasi tersebut), dan fungsi merokok (berapa batang rokok yang dihisap sesuai dengan perasaan subjek dalam fungsi merokok dalam kehidupan sehari-hari). Hasil penurunan perilaku merokok subjek disampaikan dengan menggunakan grafik dari data baseline pertama (pre-test), baseline kedua (post-test pertama) dan baseline ketiga (post-test kedua).

\section{HASIL PENELITIAN}

Penelitian dilakukan selama 17 hari dengan dua kali intervensi. Subjek 1 penelitian dilakukan tanggal 10 Agustus 2017 sampai 26 Agustus 2017, sedang-kan untuk subjek 2 penelitian dilakukan tanggal 16 Agustus 2017 sampai dengan 3 September 2017. Data karakteristik dan Minat-orientasi subjek mengikuti terapi dapat dilihat pada tabel 1 dan 2 .

Tabel 1. Data identitas subjek

\begin{tabular}{|l|l|l|}
\hline \multicolumn{1}{|c|}{ Keterangan } & \multicolumn{1}{|c|}{ Subjek 1 } & \multicolumn{1}{c|}{ Subjek 2 } \\
\hline Nama & MFH & NK \\
\hline Jenis kelamin & Laki-laki & Laki-laki \\
\hline Umur & 24 tahun & 18 tahun \\
\hline Pendidikan & S-1 & SMA \\
\hline Status pernikahan & Belum menikah & Belum menikah \\
\hline Pekerjaan & Mahasiswa & Pekerja swasta \\
\hline Jumlah anggota keluarga & 5 orang & 4 orang \\
\hline Urutan kelahiran & Anak pertama dari tiga bersaudara & Anak kedua dari dua bersaudara \\
\hline Pengalaman terapi sebelumnya & - & - \\
\hline Ada phobia atau traumatik & - & - \\
\hline Bahasa yang digunakan & Indonesia, Bugis & Indonesia, Jawa \\
\hline
\end{tabular}

Tabel 2. Minat dan orientasi mengikuti terapi subjek MFH dan NK

\begin{tabular}{|c|c|c|}
\hline Keterangan & MFH & $=1$ \\
\hline $\begin{array}{l}\text { Motivasi mengikuti } \\
\text { terapi }\end{array}$ & $\begin{array}{l}\text { Keinginan untuk mengurangi jumlah rokok, bahkan jika } \\
\text { bisa ingin berhenti }\end{array}$ & $\begin{array}{l}\text { Ingin mengikuti terapi untuk } \\
\text { berhenti merokok }\end{array}$ \\
\hline $\begin{array}{l}\text { Tujuan mengikuti } \\
\text { terapi }\end{array}$ & $\begin{array}{l}\text { Agar bisa men-dapat terapi gu-na mengurangi jumlah } \\
\text { rokok bahkan berhenti merokok }\end{array}$ & Ingin berhenti merokok \\
\hline $\begin{array}{l}\text { Harapan mengikuti } \\
\text { terapi }\end{array}$ & Bisa mengurangi bahkan berhenti merokok & $\begin{array}{l}\text { Agar tidak merokok lagi di kemudian } \\
\text { hari }\end{array}$ \\
\hline $\begin{array}{l}\text { Beberapa hal yang } \\
\text { menguatkan klien } \\
\text { untuk tetap merokok }\end{array}$ & $\begin{array}{l}\text { - Kebiasaan } \\
\text { - Gaya hidup } \\
\text { - Salah satu instrument menambah teman }\end{array}$ & $\begin{array}{l}\text { Karena ada keinginan merokok dan } \\
\text { adanya pengaruh dari lingkungan } \\
\text { pergaulan yaitu teman }\end{array}$ \\
\hline $\begin{array}{l}\text { Beberapa hal yang } \\
\text { menguatkan klien } \\
\text { untuk berhenti } \\
\text { merokok }\end{array}$ & $\begin{array}{l}\text { - Harga rokok semakin mahal } \\
\text { - Bahaya rokok bagi kesehatan }\end{array}$ & $\begin{array}{l}\text { - Ingin mendaftar Polri } \\
\text { - Ingin sehat }\end{array}$ \\
\hline
\end{tabular}




\section{Penurunan perilaku merokok}

a. Subjek MFH

Hasil penurunan perilaku merokok untuk MFH dapat dilihat berdasarkan self report dengan behavioral checklist yang ditampilkan dalam gambar 1. Analisis pada gambar 1 dilaporkan bahwa frekuensi merokok subjek MFH dalam kategori perokok berat (lebih dari 15 batang) sebelum dilakukan intervensi. Kategori perokok berat tersebut merujuk pada intensi merokok dari Aritonang (1997) dan Komalasari dan Helmi (2000) yaitu klasifikasi perokok berdasarkan banyaknya rokok yang dihisap: 1-4 ba-tang kategori ringan, 4-15 batang kategori sedang, dan lebih dari 15 batang kategori berat. Hasil pengukuran selama 5 hari sebelum intervensi adalah sebagai berikut: pada hari 1 (20 batang), hari 2 (22 batang), hari 3 (20 batang), hari 4 (21 batang) dan hari 5 (22 batang). Setelah 5 hari pengukuran baseline pertama (A1), hari ke-6 dilakukan intervensi hipnoterapi dengan part therapy. Setelah intervensi dilakukan pengukuran selama 5 hari sebagai data baseline kedua (A2). Hasil pengukuran 5 hari setelah intervensi pertama adalah sebagai berikut: hari 7 (13 batang), hari 8 (15 batang), hari 9 (12 batang), hari 10 (10 batang) dan hari 11 (11 batang). Terjadi penurunan intensi merokok setelah intervensi pertama pada subjek MFH. Kategori intensi merokok subjek MFH setelah intervensi pertama adalah kategori sedang (4-15 batang). Setelah pengukuran intervensi pertama selama 5 hari, selanjutnya dilakukan inter-vensi kedua pada hari ke-12 menggu-nakan hipnoterapi dengan part therapy. Setelah intervensi kedua dilakukan peng-ukuran selama 5 hari sebagai dapat baseline ketiga (A3). Hasil pengukuran adalah sebagai berikut: hari 13 (7 batang), hari 14 (8 batang), hari 15 (5 batang), hari 16 (8 batang) dan hari 17 (5 batang). Terjadi penurunan intensi merokok setelah intervensi kedua pada subjek MFH. Kategori intensi merokok subjek MFH setelah intervensi kedua adalah kategori sedang (4-15 batang). Dari hasil penelitian ini dapat dikatakan bahwa terjadi penurunan intensi merokok pada subjek MFH baik setelah intervensi pertama maupun intervensi kedua. Hal ini dapat dilihat dari hasil perbandingan intensi merokok antara data baseline pertama dibandingkan data baseline kedua (setelah intervensi pertama), data baseline pertama dibandingkan data baseline ketiga (setelah intervensi kedua), serta data baseline kedua dibandingkan dengan baseline ketiga.

Tabel 3. Tempat merokok MFH

\begin{tabular}{|l|c|c|c|c|c|}
\hline \multicolumn{1}{|c|}{ Indikator } & \multicolumn{3}{|c|}{ Pengukuran (hari/batang) } \\
\hline & H- & H-2 & H-3 & H-4 & H-5 \\
\hline Warung makan & 1 & & & & \\
\hline Kampus/ tempat kerja & 5 & 7 & 5 & 5 & 5 \\
\hline $\begin{array}{l}\text { Kamar pribadi/kamar } \\
\text { tidur/rumah }\end{array}$ & 5 & 5 & 5 & 6 & 7 \\
\hline Toilet/kamar mandi & 7 & 7 & 7 & 7 & 7 \\
\hline \multicolumn{1}{|c|}{ Indikator } & 3 & 3 & 3 & 3 & 3 \\
\hline Kamar pribadi/kamar & H- & H-8 & H-9 & H-10 & H-11 \\
\hline tidur/rumah & 7 & & & & \\
\hline Toilet/kamar mandi & 8 & 10 & 10 & 9 & 8 \\
\hline \multicolumn{1}{|c|}{ Indikator } & 5 & 5 & 2 & 1 & 3 \\
\hline Intensi mero-kok (sedang) & 7 & 8 & 5 & 8 & 5 \\
\hline Warung makan & 2 & 2 & 1 & 2 & 1 \\
\hline Kampus/ tempat kerja & 2 & 2 & 1 & 2 & 1 \\
\hline Kamar pribadi/kamar tidur/ & 2 & 2 & 2 & 3 & 2 \\
\hline rumah & & & & & \\
\hline Toilet/kamar mandi & 1 & 2 & 1 & 1 & 1 \\
\hline
\end{tabular}




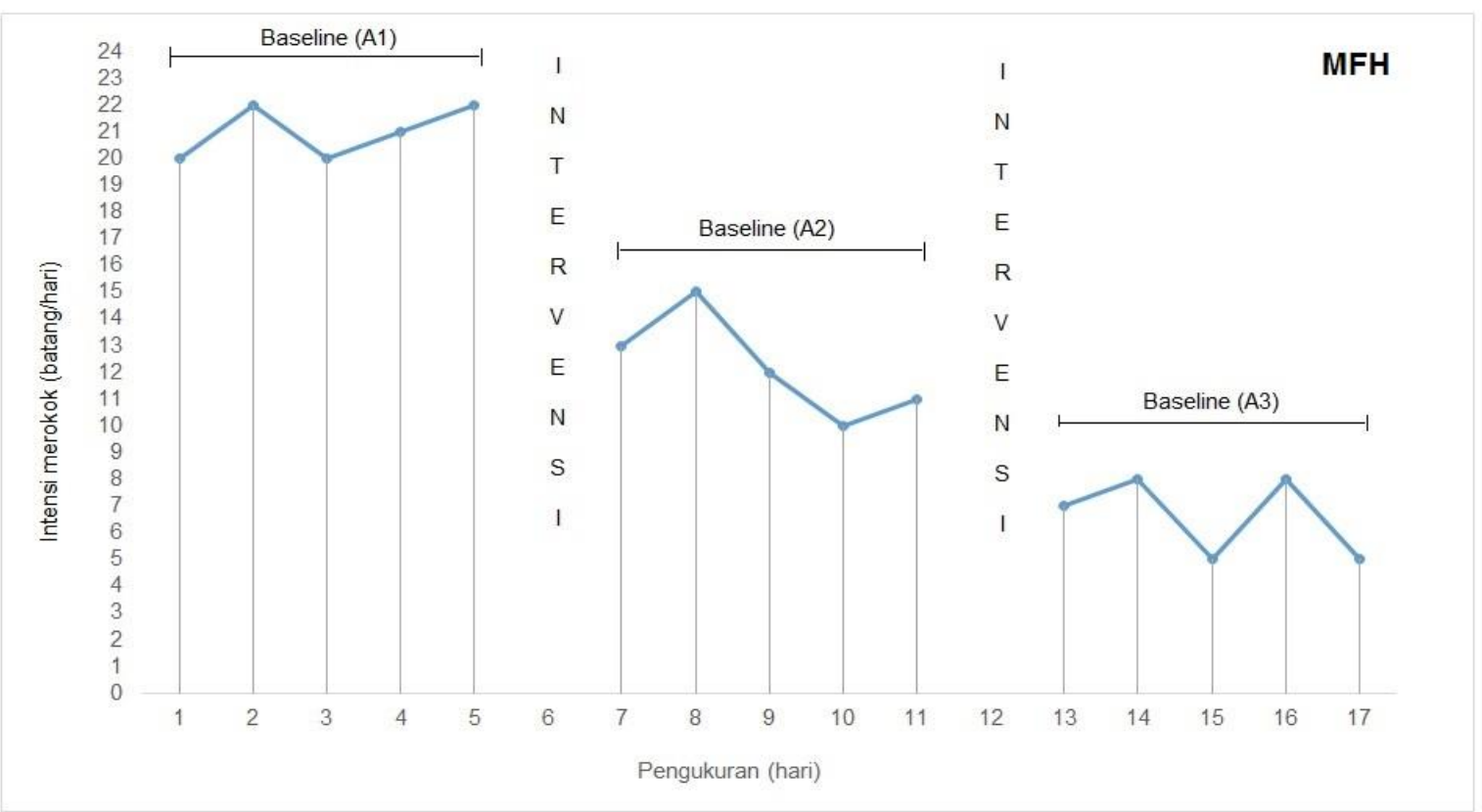

Gambar 1. Self report frekuensi perilaku merokok berdasarkan intensi merokok subjek MFH selama 17 hari

Pengukuran data self report dengan behavioral checklist selanjutnya adalah frekuensi merokok dilihat berdasarkan tempat merokok, situasi merokok dan alasan merokok.

Tabel 4. Situasi merokok MFH

\begin{tabular}{|l|c|c|c|c|c|}
\hline \multicolumn{1}{|c|}{ Indikator } & \multicolumn{5}{c|}{ Pengukuran (hari/batang) } \\
\cline { 2 - 7 } & H-1 & H-2 & H-3 & H-4 & H-5 \\
\hline Saat berkum-pul dengan teman & 12 & 14 & 12 & 11 & 14 \\
\hline $\begin{array}{l}\text { Merokok di semua situasi dan dipengaruhi } \\
\text { keadaan }\end{array}$ & 8 & 8 & 8 & 6 & 8 \\
\hline \multicolumn{1}{|c|}{ Indikator } & H-7 & H-8 & H-9 & H-10 & H-11 \\
\hline $\begin{array}{l}\text { Saat berkum-pul teman } \\
\text { Indikator }\end{array}$ & 8 & 10 & 10 & 8 & 7 \\
\hline $\begin{array}{l}\text { Merokok di semua situasi dan dipengaruhi } \\
\text { keadaan }\end{array}$ & 5 & 5 & 2 & 2 & 4 \\
\hline $\begin{array}{l}\text { Saat berkum-pul teman } \\
\text { Merokok di semua situasi dan dipengaruhi }\end{array}$ & H-13 & H-14 & H-15 & H-16 & H-17 \\
\hline $\begin{array}{l}\text { keadaan } \\
\text { Mean }\end{array}$ & 4 & 6 & 2 & 5 & 4 \\
\hline
\end{tabular}


Tabel 5. Fungsi merokok dalam sehari-hari MFH

\begin{tabular}{|l|c|c|c|c|c|}
\hline \multirow{2}{*}{ Indikator } & \multicolumn{5}{|c|}{ Pengukuran (hari/batang) } \\
\cline { 2 - 6 } & H-1 & H-2 & H-3 & H-4 & H-5 \\
\hline Menambah kenikmatan & 10 & 12 & 10 & 10 & 12 \\
\hline Menyenangkan perasaan & 5 & 5 & 5 & 5 & 5 \\
\hline Kebiasaan & 5 & 5 & 5 & 5 & 5 \\
\hline \multicolumn{1}{|c|}{ Indikator } & H-7 & H-8 & H-9 & H-10 & H-11 \\
\hline Indikator & 10 & 12 & 10 & 8 & 8 \\
\hline Kebiasaan perasaan & 3 & 3 & 2 & 2 & 3 \\
\hline $\begin{array}{l}\text { Menamangkan kenikmatan } \\
\text { Menyenangkan perasaan }\end{array}$ & H-13 & H-14 & H-15 & H-16 & H-17 \\
\hline Mengurangi rasa cemas, marah, gelisah & 2 & 2 & 2 & 2 & 2 \\
\hline Kebiasaan & 2 & 2 & 1 & 3 & 1 \\
\hline
\end{tabular}

b. Subjek NK

Hasil penurunan perilaku merokok untuk NK dapat dilihat berdasarkan self report dengan behavioral checklist yang ditampilkan dalam gambar 2. Analisis pada gambar 2 dilaporkan bahwa frekuensi merokok subjek NK dalam kategori perokok sedang (4-15 batang) sebelum dilakukan intervensi. Kategori perokok sedang tersebut meru-juk pada intensi merokok dari Aritonang (1997) dan Komalasari dan Helmi (2000) yaitu klasifikasi perokok berdasarkan banyaknya rokok yang dihisap: 1-4 ba-tang kategori ringan, 4-15 batang kategori sedang, dan lebih dari 15 batang kategori berat. Hasil pengukuran selama 5 hari sebelum intervensi adalah sebagai berikut: pada hari 1 ( 9 batang), hari 2 ( 8 batang), hari 3 ( 6 batang), hari 4 ( 8 batang) dan hari 5 ( 8 batang). Setelah 5 hari pengukuran baseline pertama (A1), hari ke-6 dilakukan intervensi hipnoterapi dengan part therapy. Setelah intervensi dilakukan pengukuran selama 5 hari sebagai data baseline kedua (A2). Hasil pengukuran 5 hari setelah intervensi pertama adalah sebagai berikut: hari 7 (4 batang), hari 8 (3 batang), hari 9 (3 batang), hari 10 (2 batang) dan hari 11 (2 batang). Terjadi penurunan intensi mero-kok setelah intervensi pertama pada subjek NK. Kategori intensi merokok subjek NK setelah intervensi pertama adalah kategori ringan (1-4 batang). Sete-lah pengukuran intervensi pertama sela-ma 5 hari, selanjutnya dilakukan inter-vensi kedua pada hari ke-12 menggu-nakan hipnoterapi dengan part therapy. Setelah intervensi kedua dilakukan peng-ukuran selama 5 hari sebagai dapat base-line ketiga (A3). Hasil pengukuran adalah sebagai berikut: hari 13 ( 2 batang), hari 14 (1 batang), sedangkan pada hari 15 , hari 16, dan hari 17 subjek NK sudah tidak merokok. Terjadi penurunan intensi merokok setelah intervensi kedua pada subjek NK. Kategori intensi merokok subjek NK setelah intervensi kedua ada-lah kategori ringan (1-4 batang) pada hari ke 13 dan ke 14, namun setelah hari ke 15, 16, 17 subjek NK sudah tidak mero-kok. Dari hasil penelitian ini dapat dikata-kan bahwa terjadi penurunan intensi merokok pada subjek NK baik setelah intervensi pertama maupun intervensi kedua. Hal ini dapat dilihat dari hasil perbandingan intensi merokok antara data baseline pertama dibandingkan data baseline kedua (setelah intervensi per-tama), data baseline pertama dibanding-kan data baseline ketiga (setelah inter-vensi kedua), serta data baseline kedua dibandingkan dengan baseline ketiga. 
Tabel 6. Tempat merokok NK

\begin{tabular}{|l|c|c|c|c|c|}
\hline \multirow{2}{*}{ Indikator } & \multicolumn{4}{c|}{ Pengukuran (hari/batang) } \\
\cline { 2 - 7 } & H-1 & H-2 & H-3 & H-4 & H-5 \\
\hline Warung makan & 3 & 3 & 3 & 3 & 4 \\
\hline Tempat kerja & 6 & 5 & 3 & 5 & 4 \\
\hline \multicolumn{1}{|c|}{ Indikator } & H-7 & H-8 & H-9 & H-10 & H-11 \\
\hline Warung makan & 2 & 0 & 1 & 0 & 0 \\
\hline \multicolumn{1}{|c|}{ Indikator } & H-13 & H-14 & H-15 & H-16 & H-17 \\
\hline Warung makan & 0 & 1 & 0 & 0 & 0 \\
\hline
\end{tabular}

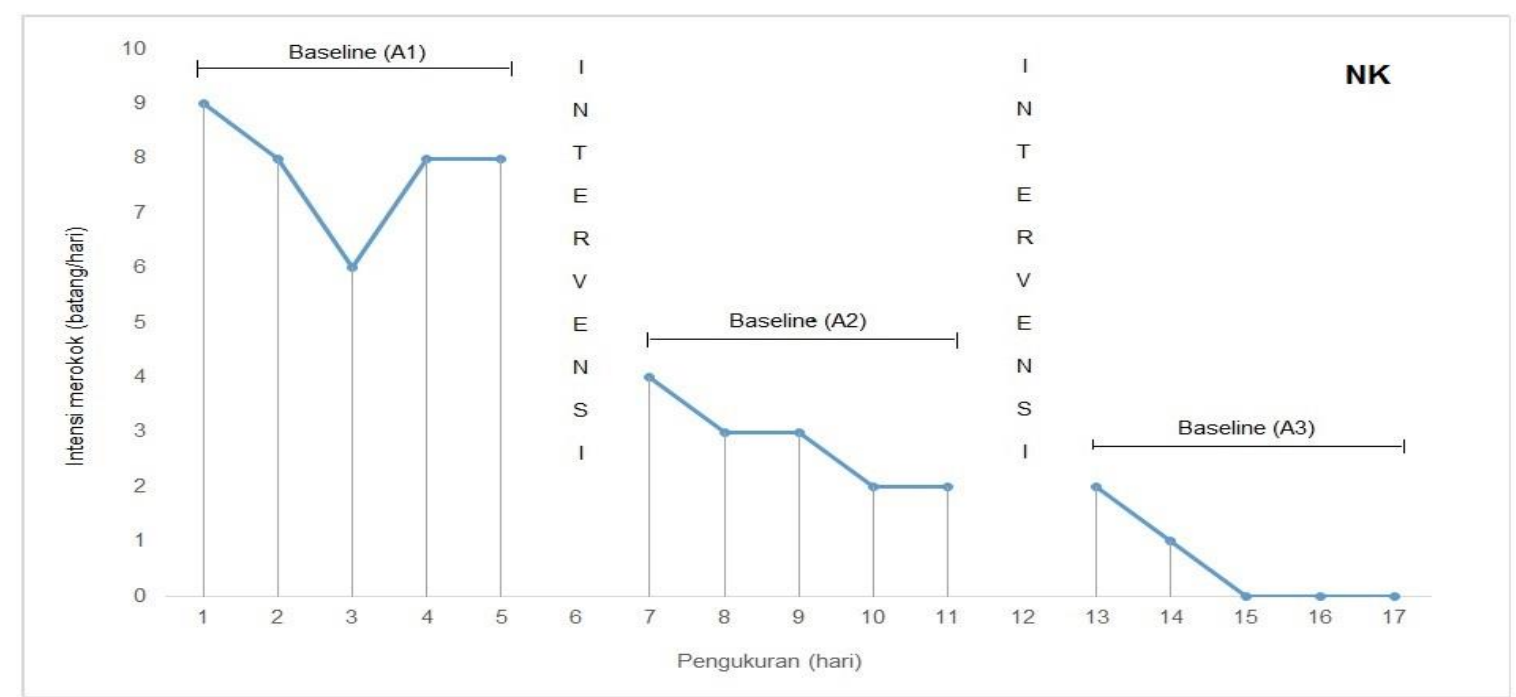

Gambar 2. Self report frekuensi perilaku merokok berdasarkan intensi merokok subjek NK selama 17 hari

Pengukuran data self report dengan behavioral checklist selanjutnya adalah frekuensi merokok berdasarkan tempat merokok, situasi merokok dan alasan merokok adalah sebagai berikut.

Tabel 7. Situasi merokok NK

\begin{tabular}{|c|c|c|c|c|c|}
\hline \multirow{2}{*}{ Indikator } & \multicolumn{5}{c|}{ Pengukuran (hari/batang) } \\
\cline { 2 - 7 } & H-1 & H-2 & H-3 & H-4 & H-5 \\
\hline Saat berkumpul dengan teman & 9 & 8 & 6 & 8 & 8 \\
\hline Cuaca dingin & 6 & 5 & 0 & 5 & 0 \\
\hline \multicolumn{1}{|c|}{ Indikator } & H-7 & H-8 & H-9 & H-10 & H-11 \\
\hline Saat berkumpul dengan teman & 3 & 3 & 3 & 2 & 2 \\
\hline $\begin{array}{l}\text { Merokok di semua situasi dan } \\
\text { dipengaruhi oleh keadaan }\end{array}$ & 1 & 0 & 0 & 0 & 0 \\
\hline \multicolumn{1}{|c|}{ Indikator } & H-13 & H-14 & H-15 & H-16 & H-17 \\
\hline Saat berkumpul dengan teman & 2 & 0 & 0 & 0 & 0 \\
\hline
\end{tabular}


Tabel 8. Fungsi merokok dalam sehari-hari NK

\begin{tabular}{|l|c|c|c|c|c|}
\hline \multirow{2}{*}{\multicolumn{1}{c|}{ Indikator }} & \multicolumn{5}{c|}{ Pengukuran (hari/batang) } \\
\cline { 2 - 7 } & H-1 & H-2 & H-3 & H-4 & H-5 \\
\hline Menambah kenikmatan & 3 & 0 & 0 & 0 & 0 \\
\hline Menyenangkan perasaan & 3 & 3 & 0 & 3 & 8 \\
\hline Mengurangi rasa cemas, marah, gelisah & 0 & 0 & 0 & 0 & 0 \\
\hline Kebiasaan Indikator & 0 & 0 & 0 & 0 & 0 \\
\hline \multicolumn{1}{|c|}{ Indikator } & H-7 & H-8 & H-9 & H-10 & H-11 \\
\hline Menambah kenikmatan & 0 & 0 & 0 & 0 & 0 \\
\hline Menyenangkan perasaan & 0 & 0 & 0 & 0 & 0 \\
\hline Mengurangi rasa cemas, marah, gelisah & 0 & 0 & 0 & 0 & 0 \\
\hline Kebiasaan & 0 & 0 & 0 & 0 & 0 \\
\hline & H-13 & H-14 & H-15 & H-16 & H-17 \\
\hline Menambah kenikmatan & 0 & 0 & 0 & 0 & 0 \\
\hline Menyenangkan perasaan & 0 & 0 & 0 & 0 & 0 \\
\hline Mengurangi rasa cemas, marah, gelisah & 0 & 0 & 0 & 0 & 0 \\
\hline Kebiasaan & 0 & 0 & 0 & 0 & 0 \\
\hline
\end{tabular}

\section{Hasil kualitatif}

\section{a. Subjek MHF}

Subjek MFH pertama kali merokok waktu SD karena ikut-ikutan dan coba-coba saat bermain dengan temanteman, waktu SMA mulai menjadi perokok aktif, dan setelah kuliah merokok dirasakan dapat menimbulkan kenikmatan. Setiap harinya subjek merokok karena rokok dapat membuat rileks, menghilangkan suntuk atau bosan, menyenangkan perasaan, menambah kenikmatan, dan memudahkan mencari inspirasi. Namun ada beberapa kerugian dari perilaku merokok tersebut antara lain: meng-ganggu kesehatan yaitu pernafasan seperti ketindih beban sehingga menjadi-kan sesak, harga rokok yang semakin mahal berakibat pada pemborosan, dan mulai ada kesadaran untuk menghormati teman yang tidak merokok, karena asap rokok dapat mengganggu kesehatan orang lain. Sebelum hipnoterapi dengan part therapy dilakukan, subjek mengata-kan kepada hipnoterapis bahwa harapan dari mengikuti hipnoterapi dengan part therapy ini antara lain adalah: mengurangi cost yang dikeluarkan, memperbaiki pola hidup, dan menjaga kesehatan.

Subjek MHF menginginkan perilaku merokoknya berkurang, namun kalau bisa berhenti total. Subjek sudah sering men-coba namun gagal. Harapan subjek dengan mengikuti hipnoterapi dengan part therapy adalah untuk mendapatkan terapi yang dapat mengurangi dan meng-hentikan perilaku merokoknya.

Setelah menjalankan hipnoterapi dengan part therapy yang pertama, subjek mengatakan bahwa perilaku mero-koknya sudah turun kurang lebih $40-60 \%$ yaitu yang biasa dua bungkus rokok untuk satu hari, sudah berkurang kadang-kadang satu bungkus untuk satu hari, dan bahkan masih ada sisa antara 2-3 batang untuk ukuran rokok dalam kemasan 16 batang. Subjek juga mengatakan bahwa ada perasaan plong dan fresh setelah selesai menjalankan hipnoterapi dengan part therapy pertama.

Pada waktu menjalankan hipnote-rapi dengan part therapy yang kedua, subjek MFH merasakan lebih fresh. Subjek mengatakan bahwa pernafasan-nya plong, serasa menghilangkan batu yang ada di dada. Setelah sesi kedua, perilaku merokok sudah sangat ber-kurang. Namun subjek masih sulit meng-hilangkan merokok waktu kondisi bosan dan banyak pikiran. Subjek bersyukur karena setelah terapi kedua perilaku me-rokok sudah banyak berkurang. Subyek mengatakan bahwa mulai membeli rokok dengan kemasan 12 batang dan dapat digunakan selama 2 hari. Subjek sudah ada kesadaran diri, lebih mempunyai keinginan kuat, dan lebih menata hidup sehat dengan pola baru untuk berhenti merokok. Subjek mengatakan bahwa pe-nurunan perilaku merokoknya dirasakan sudah signifikan, hal ini karena penu-runan perilaku merokoknya berkurang 
sangat banyak. Saat tidak merokok ber-sama teman-temannya subjek merasakan biasa-biasa saja, dan pertemanan subjek berjalan lancar.

Untuk evaluasi kegiatan hipnoterapi dengan part therapy subjek mengatakan bahwa mendapatkan pengetahuan baru tentang pengobatan perilaku merokok dengan metode hipnoterapi. Terapi dika-takan cukup bermanfaat dan cukup meru-bah perilaku merokoknya. Adapun pelak-sana hipnoterapi dengan part therapy dikatakan oleh subjek sangat menguasai materi.

\section{b. NK}

Subjek NK pertama kali merokok waktu SMP karena pengaruh dari teman-teman. Pertama kali merokok sekitar 1 sampai 5 batang, sampai sekarang subjek masih merokok. Subjek tidak per-nah merokok di rumah, karena takut kedua orang tuanya. Kakak subyek tidak pernah merokok, subjek ingin seperti kakaknya. Subjek selalu ingin merokok apabila berkumpul dengan teman-teman-nya. Subjek pernah berhenti merokok selama 6 bulan, namun kembali lagi merokok sampai sekarang. Dulu saat berhenti merokok, subjek menggunakan cara dengan berolah raga, dan ada penguat dari subjek yaitu keinginan seperti ayah dan kakaknya yang tidak merokok. Harapan yang dikatakan oleh subjek NK dengan mengurangi atau ber-henti merokok adalah untuk cita-citanya yang menginginkan menjadi polisi atau angkatan, untuk masa depannya yaitu tidak boros, uangnya dapat di tabung, dan untuk menjaga kesehatan untuk häri ini dan hari esok.

Setelah menjalankan hipnoterapi dengan part therapy yang pertama, subjek mengatakan bahwa perilaku merokoknya sudah turun yaitu antara 2-4 batang perharinya. Subjek masih sulit untuk menolak temannya, tapi saat sen-diri sudah dapat mengontrol perilaku merokoknya. Subjek NK juga mengatakan bahwa ada perasaan segar setelah selesai menjalankan hipnoterapi dengan part therapy pertama.

Pada waktu menjalankan hipno-terapi dengan part therapy yang kedua, subjek NK mengatakan bahwa merasa senang karena merokoknya sudah berkurang. Subjek merasakan manfaat dari perilakunya ini yaitu badan menjadi terasa enak dan nafasnya lancar. Setelah terapi kedua, subjek sudah dapat menguatkan niatnya untuk berhenti merokok, dan saat bersama temannya juga sudah dapat menolak, sehingga peri-laku merokoknya dapat dikurangi, bahkan sampai berhenti merokok. Subjek menga-takan bahwa saat ditawari merokok oleh temannya, kalimat ini yang disampaikan, "aku lagi menjalani terapi", sehingga subjek mudah untuk menolaknya.

Untuk evaluasi kegiatan hipnoterapi dengan part therapy subjek mengatakan bahwa telah mendapatkan pengetahuan baru tentang cara untuk mengurangi atau berhenti perilaku merokok dengan meto-de hipnoterapi. Terapi dikatakan cukup bermanfaat dan sangat merubah perilaku merokoknya. Adapun pelaksana hipnote-rapi dengan part therapy dikatakan oleh subjek sangat menguasai materi. Subjek mengatakan bahwa tempat terapi nyaman dan terapinya enak, namun durasi terapinya terlalu lama. Saran yang diberikan oleh subjek adalah waktu lebih dapat dipercepat atau durasinya lebih diperpendek, namun tetap dengan hasil yang lebih baik.

\section{PEMBAHASAN}

Berdasarkan hasil penelitian dapat dilaporkan bahwa hipotesis dalam peneli-tian ini dapat diterima. Hal ini ditunjukkan dari adanya pengaruh hipnoterapi dengan part therapy untuk penurunan perilaku merokok. Pengaruh tersebut terlihat dari adanya perbedaan perilaku merokok subjek sebelum dan sesudah dilakukan intervensi hipnoterapi dengan part therapy. Perilaku merokok subjek menga-lami penurunan sesudah diberikan inter-vensi hipnoterapi dengan part therapy. Penurunan perilaku merokok dilihat dari beberapa faktor perilaku merokok yaitu intensi merokok, tempat merokok, situasi merokok, dan fungsi merokok dalam kehidupan sehari-hari (Aritonang, 1997; Poerwadarminta dalam Perwitasari, 2006; Komalasari \& Helmi, 2000).

Apabila dilihat sampai saat ini, rokok merupakan salah satu permasa-lahan rumit dalam kehidupan masyarakat. Di Indonesia perokok lebih banyak laki-laki dibandingkan perempuan (64,9\% dibandingkan 2,1\%), usia 10-14 tahun sebanyak 1,4\%, tidak bekerja sebanyak 9,9\%. Di Yogyakarta diperkirakan orang merokok rata-rata 10 batang/hari (Riskes-das, 2013). Ada beberapa alasan seorang perokok untuk tetap 
merokok seperti merokok dapat meningkatkan per-gaulan dan persahabatan (Prawitasari, 2012), memberikan kenikmatan, kenya-manan dan dapat mengurangi stress (Parrot dalam Nasution, 2007), merokok juga dapat menimbulkan perasaan dewasa, serta dapat terlihat matang dan jantan (Prawitasari, 2012), namun di sisi lain ada alasan yang membuat perokok berkeinginan untuk berhenti merokok seperti merokok dapat membuat kecan-duan, mengganggu kesehatan, ekonomi, dan hubungan sosial.

Beberapa alasan tersebut di atas mendukung hasil penelitian ini (tabel 2) bahwa kedua subjek penelitian mem-punyai alasan-alasan tersebut. Alasan kedua subjek penelitian berkaitan dengan perilaku yang memperkuat merokok ada-lah kebiasaan, gaya hidup, salah satu instrument menambah teman, dan lingkungan pergaulan yaitu pengaruh teman, sedangkan alasan yang berkaitan dengan perilaku untuk mengurangi dan berhenti merokok adalah harga rokok yang semakin tinggi, bahaya rokok bagi kesehatan, dan untuk mengejar cita-cita.

Dari bagian-bagian atau parts yang bertentangan tentang alasan berhenti merokok atau tetap merokok tersebut, ada salah satu bagian atau part dari kedua klien yaitu keinginan untuk mengurangi atau berhenti merokok (tabel 2), alasan yang ada pada kedua klien tersebut dapat menjadi sebuah alasan untuk memilih sebuah intervensi untuk mengurangi atau berhenti merokok. Intervensi yang dipilih adalah hipnoterapi dengan part therapy.

Hasil penelitian pada gambar 1 dan 2 memperlihatkan hasil penelitian tentang intensi merokok. Pada grafik tersebut ditunjukkan penurunan intensi merokok kedua subjek penelitian (gambar 1: subjek MFH dan gambar 2: subjek NK). Terjadi penurunan yang signifikan intensi merokok kedua subjek penelitian. Penurunan intensi merokok tersebut dapat dilihat dari pengukuran data baseline pertama (pre-test) ke data baseline kedua (post-test pertama), pengukuran data baseline pertama (pre-test) ke data baseline ketiga (posttest kedua), dan pengukuran data baseline kedua (post-test pertama) ke data baseline ketiga (post-test kedua). Penurunan intensi merokok dilihat dari frekuensi merokok (per batangnya) yang semakin hari semakin menurun dari pengukuran-pengukuran yan dilakukan selama 15 hari secara berturut-turut.

Hasil penurunan intensi merokok didukung juga dengan pembuktian dari faktor lain yaitu tempat merokok, situasi merokok, dan fungsi merokok dalam kehidupan sehari-hari. Faktor-faktor yang juga diukur ini memperlihatkan penurunan yang signifikan. Hal ini dapat dilihat pada tempat merokok, situasi merokok, dan fungsi merokok dalam kehidupan yang selalu menurun perharinya. Tempat-tempat, situasi-situasi dan fungsi merokok yang frekuensi merokoknya cenderung tinggi pada data baseline pertama (pre-test) setelah baseline kedua (post-test pertama) dan baseline ketiga (post-test kedua) terlihat penurunan (gambar 3, 4, 5 untuk subjek MFH, sedangkan gambar 6, 7, 8 subjek NK). Hasil penelitian ini mem-perlihatkan bahwa tempat-tempat yang frekuensi merokoknya tinggi untuk subjek MFH yaitu kamar pribadi, kampus dan warung makan, sedangkan subjek NK yaitu warung makan. Situasi merokok untuk subjek MFH maupun subjek NK yaitu saat berkumpul dengan teman. Adapun untuk fungsi merokok untuk subjek MFH yaitu menambah kenikmatan, menyenangkan perasaan, dan mengu-rangi rasa cemas, marah dan gelisah, sedangkan subjek NK yaitu menambah kenikmatan. Setelah dilakukan hipno-terapi dengan part therapy baik intensi merokok, tempat merokok, situasi mero-kok dan fungsi merokok mengalami penurunan, walaupun pada faktor-faktor tersebut subjek masih melakukan perilaku merokoknya.

Pembuktian hasil penelitian juga dapat dilaporkan dari hasil wawancara dengan kedua subjek penelitian. Inti dari wawancara bahwa subjek MFH setelah intervensi merasakan fresh dan perna-fasannya plong, serasa menghilangkan batu yang ada di dada. Dari segi perilaku subjek sudah ada kesadaran diri, lebih mempunyai keinginan kuat, dan lebih menata hidup sehat dengan pola baru untuk berhenti merokok. Subjek mengatakan bahwa penurunan perilaku mero-koknya dirasakan sudah signifikan. Ada-pun hal yang dirasakan subjek NK setelah intervensi ada perasaan segar, badan terasa enak, senang, dan nafas lancar. Dari segi perilaku subjek sudah dapat menolak ajakan teman untuk merokok, dan lebih dapat menguatkan niatnya untuk berhenti merokok.

Dari hasil penelitian terbukti bah-wa intervensi hipnoterapi dengan part therapy dapat dijadikan alternatif untuk penurunan perilaku merokok. Hasil pene-litian ini mendukung penelitian terdahulu yang menggunakan hipnoterapi untuk menurunkan perilaku merokok. Penelitian tersebut dilakukan oleh Rafael 
(2006) bahwa hipnoterapi efektif untuk menu-runkan perilaku merokok bahkan untuk berhenti merokok, karena hipnoterapi menjangkau alam bawah sadar manusia untuk diberikan sugesti positif yang dapat merubah perilaku merokoknya. Rafael melakukan penelitian terhadap 200 karya-wan dengan memberikan group therapy, karyawan dikumpulkan dalam satu ruangan lalu diberikan terapi pada saat yang bersamaan dan satu bulan kemu-dian 95\% di antara karyawan yang diterapi telah berhenti merokok.

Penelitian kasus yang dilakukan Hunter (2015) juga sebagai bukti dari ke-berhasilan hipnoterapi dengan part therapy. Pada salah satu kasus perilaku merokok yang ditangani dilaporkan bah-wa klien pada waktu proses pelisanan mengatakan, "ia tidak benar-benar ingin berhenti secara total". Klien menam-bahkan, bawah sadarnya bersedia beker-jasama sebagai perokok terkendali yang hanya sesekali menyalakan rokok. Setelah keluar dari hipnosis dan ber-diskusi, klien dikuatkan dengan beberapa pedoman mengenai cara menjaga kendali sadar supaya tindakan merokoknya minimum - termasuk menjauhkan rokok dari jangkauan tangan sehingga klien dapat mengambil keputusan secara sadar sebelum menyalakannya. Bawah sadar klien menegaskan bahwa klien menerima kesepakatan tersebut saat dilakukan hipnosis kembali. Sesi hipnoterapi diakhiri dengan pembayangan terprogram dan sugesti langsung supaya klien menarik satu kali nafas dalam setiap klien menyalakan rokok secara otomatis. Klien puas dengan hasil yang dicapainya, sehingga klien dapat mengurangi jumlah rokok lebih dari satu lusin setiap harinya, dan klien berkata bahwa ia seharusnya benar-benar berhenti satu atau dua tahun lagi. Pada kasus lain yang ditangani Hunter (2015) dilaporkan bahwa setelah hipnoterapi dengan part therapy, klien dapat menyadari, bahwa kekuatannya untuk memilih dan saatnya mengambil/keputusan sendiri, bukan diatur oleh kebiasaan merokoknya, sehingga perilaku merokoknya dapat dikurangi atau dihen-tikannya.

Pada penelitian ini, kesepakatan yang telah dibuat oleh subjek MFH untuk mengurangi atau menghentikan rokok dengan membuat alternatif-alternatif peri-laku seperti menganti rokok dengan permen, banyakbanyak mendekatkan diri pada Tuhan dengan berdzikir, olah raga dan jangan membeli rokok, sedangkan untuk subjek NK seperti ingat dada sesak, puasa, olah raga, bergaul dengan orang yang tidak merokok, menabung (uangnya di tabung), dan makan permen.

Pada pendekatan hipnoterapi dengan part therapy keputusan penye-lesaian masalah diserahkan kepada klien melalui proses hipnosis. Seorang hipno-terapis hanya sebagai fasilitator dan mediator. Tahapan-tahapan dalam hipno-terapi dengan part therapy mengacu pada pendekatan client centered yaitu (1) menekankan pada dorongan dan kemam-puan yang terdapat dalam diri individu yang berkembang, untuk hidup sehat dan menyesuaikan diri; (2) menekankan pada unsur atau aspek emosional dan tidak pada aspek intelektual; (3) menekankan pada situasi yang langsung dihadapi individu, dan tidak pada masa lampau; dan (4) menekankan pada hubungan teraputik sebagai pengalaman dalam perkembangan individu yang bersangkutan (Corey. 2010).

Hunter (2006) menyatakan bahwa terapi yang terpusat pada klien sangat ideal untuk membantu menyelesaikan konflik batin. Konflik batin terjadi apabila ada dua atau lebih bagian yang ada di alam bawah sadar yang harus memilih, namun pilihan tersebut saling berten-tangan. Pada kasus perilaku merokok, kemungkinan secara emosional seorang perokok mempunyai keinginan untuk berhenti agar mempunyai banyak energi dan dapat menjaga kesehatan, sedang-kan bagian lain menginginkan merokok karena memberikan kesenangan, dan menambah kenikmatan setelah makan. Langkah-langkah yang dapat digunakan dalam terapi yang berpusat pada klien, dalam hal ini adalah hipnoterapi dengan part therapy antara lain adalah (1) Iden-tifikasi bagiannya; (2) Dapatkan hu-bungan baik (puji bagian); (3) Panggil bagian itu; (4) Terimakasih telah muncul; (5) Temukan tujuannya; (6) Panggil bagian lain yang sesuai; (7) negosiasikan dan lakukan mediasi; (8) Mintalah bagian untuk mencapai kesepakatan; (9) Konfir-masikan dan rangkum ketentuan kesepa-katan; (10) Beri sugesti langsung yang sesuai; dan (11) Padukan bagianbagian (proses part therapy selesai).

Di dalam tahapan hipnoterapi dengan part therapy ada tahapan pem-berian sugesti langsung yang sesuai. Hal ini juga dapat menambah intervensi ini layak direkomendasikan untuk penu-runan perilaku merokok. Hal ini karena saat hipnosis, sebuah sugesti (untuk penurunan perilaku merokok) setiap kali memasuki pikiran bawah sadar, sugesti pasti memberikan efek atau pengaruh. Efek ini disebut dengan post hypnotic effect atau 
efek pasca hipnosis. Fakhri (2008) membahasakan sugesti seperti afirmasi dalam istilah psikologi, yaitu sebuah pesan positif yang dapat ber-pengaruh pada sikap dan perilaku indi-vidu karena pesan itu diberikan pada saat subjek berada dalam keadaan tidur hipnosis. Sugesti yang positif dan sesuai dengan yang dikehendaki oleh subjek akan dengan mudah diterima tanpa ada penolakan, sebaliknya sugesti negatif yang tidak sesuai atau bertolak belakang dengan keyakinan, kepercayaan dan keinginan subjek akan dengan mudah ditolak atau tidak diaplikasikan dalam kehidupan sehari hari subjek (Gunawan, 2010). Sugesti yang digunakan dalam penelitian ini khusus ditujukan untuk keperluan berhenti merokok yang telah dituliskan dalam modul penelitian.

Perbedaan disonansi dapat dijadi-kan tolak ukur keberhasilan hipnoterapi dengan part therapy untuk penurunan perilaku merokok. Dari penjelasan pelaksanaan hipnoterapi dengan part therapy yang telah dilakukan terhadap kedua subjek, dapat diringkas sumber perbedaan disonansi antara kedua subjek sebagai berikut:

Tabel 9. Perbedaan disonansi subjek MFH dan NK

\begin{tabular}{|c|c|c|}
\hline Disonansi & MFH & NK \\
\hline $\begin{array}{l}\text { Keinginan } \\
\text { merokok }\end{array}$ & $\begin{array}{l}\text { - Keinginan untuk rileks } \\
\text { - Bila rileks dapat dengan cepat mengerjakan tugas } \\
\text { kuliah } \\
\text { - Bila rileks dapat konsentrasi belajar } \\
\text { - Bila cepat mengerjakan tugas kuliah dan } \\
\text { konsentrasi belajar cepat lulus kuliah } \\
\text { - Ingin menjadi tenaga pengajar } \\
\text { - Dapat segera mencapai cita-cita, dapat kepuasan } \\
\text { dan kenikmatan karena dapat menjadi role model } \\
\text { di daerah asalnya }\end{array}$ & $\begin{array}{l}\text { - Merokok karena ingin } \\
\text { mendapatkan teman } \\
\text { - Untuk mencari kesenangan } \\
\text { - Untuk mengurangi stress }\end{array}$ \\
\hline $\begin{array}{l}\text { Keinginan } \\
\text { berhenti } \\
\text { merokok }\end{array}$ & $\begin{array}{l}\text { - Agar lebih sehat karena pernafasannya tidak lancar } \\
\text { - Agar mimpi-mimpi dapat tercapai } \\
\text { - Kepuasan pribadi apabila mimpi-mimpi tercapai } \\
\text { - Rasa bahagia dan bangga bisa berhenti merokok } \\
\text { - Bahagia untuk dirinya sendiri karena bisa berhenti } \\
\text { merokok }\end{array}$ & $\begin{array}{l}\text { - Untuk tujuan cita-cita } \\
\text { - Untuk masa depan } \\
\text { - Untuk kesehatan hari ini dan } \\
\text { besok }\end{array}$ \\
\hline
\end{tabular}

Kelemahan penelitian adalah subjek melakukan self report, sehingga ketidakakuratan data menjadi perhatian yaitu adanya kesengajaan subjek untuk tidak memberikan jawaban atau pengu-kuran yang sesungguhnya. Alasan subjek enggan memberikan jawaban yang se-sungguhnya adalah karena hal-hal yang diungkapkan bersifat sangat pribadi se-hingga menimbulkan kekhawatiran men-datangkan penilaian negatif dari orang lain. Meskipun tidak dapat dipasti-kan apakah subjek telah memberikan jawaban yang jujur (Cohen \& Swerdlik, 2005), namun subjek dalam memberikan ja-waban yang sebenarnya dapat terkait dengan situasi yang melatarbelakangi kebutuhan subjek dalam menjawab.

\section{KESIMPULAN}

Ada pengaruh hipnoterapi dengan part therapy untuk penurunan perilaku merokok. Perilaku merokok sebelum intervensi lebih tinggi dibandingkan sesu-dah intervensi. Perilaku merokok subjek MFH sebelum merokok dalam kategori berat, setelah intervensi pertama dan kedua mengalami penurunan yaitu dalam kategori sedang. Adapun perilaku mero-kok subjek NK sebelum merokok dalam kategori sedang, setelah 
intervensi per-tama dan kedua mengalami penurunan yaitu dalam kategori ringan, bahkan sam-pai berhenti merokok dalam pengukuran tiga hari terakhir setelah intervensi kedua.

\section{SARAN}

Hipnoterapi dengan part therapy dapat dijadikan salah satu alternatif untuk mengurangi atau menghentikan perilaku merokok. Bagi peneliti selanjutnya, hasil penelitian ini dapat dijadikan sebagai referensi atau rujukan untuk penelitian sejenis, namun perlu kiranya untuk pencatatan data penelitian selain data self report dapat ditambahan pencatatan data dari sumber lain sebagai significant others.

\section{DAFTAR PUSTAKA}

Abbot, N.C., Stead, L.F., White, A.R. \& Barnes, J., (2006). Hypnotherapy for smoking cessation, The Cochrane Database for Systematic Review. In: The Cochrane Library, the Cochrane Collaboration. Issue I. 4(2):1-8.

Abdullah, A.S., Stillman, F.A., Yang Lin, Luo, H., Zhang, Z., \& Samet, J.M., (2014). Tobacco use and smoking cessation practices among physicians in developing contries. A literature review (1984-2010). Int. J. Environ Res. Public Health, 11 (1):429-455.

Allahyani, M.H.A., (2012). The relationship between cognitive dissonance and decision making styles in sample of female students at the University of Umm Al Qura. Journal Education Spring, 132(3): 607614.

Aritonang, M.R., (1997). Fenomena wanita merokok. Skripsi, tidak diterbitkan, Universitas Gadjah Mada, Yogyakarta.

Cohen, R., \& Swerdlik, M., (2005). Psychological testing and assessment: An introduction to tests and measurement. $6^{\text {th }}$ edition. Mc-Graw-Hill International.

Corey, G., (2010). Teori dan Praktik Konseling dan Psikoterapi, Bandung: Refika Aditama.

Depkes RI. (2009). Undang-undang Nomor 36 tahun 2009 tentang Kesehatan.

Elkins, G., \& Rajab, H., (2004). Clinical Hipnosis for smoking cessation: Preliminary results of a three-sesion intervention. International Journal of Clinical and Experimental Hipnosis. 52:73-81.

Fachri, H.A. (2008). The Real Art of Hypnosis. Jakarta: Gagas Media.

Fawzani, N., \& Triratnawati, A., (2005). Terapi Berhenti Merokok, Makara Kesehatan, 9(1):15-22.

Fraenkel, J. R., \& Wallen, N. E., (2006). How to design and evaluate research in education, ( $5^{\text {th }}$ ed.). New York: McGraw-Hill Publishing.

Gunawan, A.W., (2007). Hypnotherapy. Jakarta: Gramedia Pustaka Utama.

Hakim, A., (2010). Hipnoterapi: cara tepat dan cepat mengatasi stress, fobia, trauma dan gangguan mental lainnya. Jakarta: Transmedia Pustaka.

Hunter, C.R., (2006). Client-Centered Parts Therapy. European Journal of Clinical Hypnosis, 6(4):22-26.

Hunter, C.R., (2015). Seni Hipnoterapi: penguasaan teknik yang berpusat pada klien. Edisi keempat, Jakarta: Indeks.

Indonesian Association of Clinical Hypnothe-rapist (IACH), (2015). Professional Clinical Hypnotherapy Training. Modul Pelatihan. 11-13 Mei 2013, Yogyakarta.

Komalasari, D., \& Helmi, A.F., (2000). Faktor-faktor Perilaku Merokok pada Remaja. Jurnal Psikologi, (1):3747.

Latipun, (2002). Psikologi eksperimen, Ma-lang: Penerbit Universitas Muhamma-diyah Press.

Meyers, A., \& Hansen, C.H., (2002). Experimental Psychology, $5^{\text {th }}$ ed, USA: Wadsworth, Thomson learning.

Nasution, I.K., (2007). Perilaku Merokok pada Remaja. Tesis, tidak dipublikasikan. Program Studi Psikologi, Fakultas Kedokteran, Universitas Sumatera Utara, Medan.

Perwitasari, R., (2006). Motivasi dan perilaku merokok pada mahasiswa ditinjau dari internal locus of control dan extrenal locus of control. Skripsi, Tidak dipublikasikan, Jurusan Psikologi, Fakultas Ilmu Pendidikan Universitas Negeri Semarang, Semarang. 
PPDGJ III, (1993). Pedoman Penggolongan dan Diagnosis Gangguan Jiwa di Indonesia III, Cetakan Pertama, Departemen Kesehatan RI, Direktorat Jenderal Pelayanan Medik, Jakarta.

Prawitasari, J.E., (2012). Psikologi Terapan: Melintas Batas Disiplin Ilmu. Jakarta: Erlangga.

Rafael, R., (2006). Hipnoterapi: Quit Smoking. Jakarta: Gagas Media.

Riskesdas, (2013). Riset Kesehatan Dasar. Badan Penelitian dan Pengembangan Kesehatan Kementerian Kesehatan RI. Badan Litbangkes, Depkes RI, Jakarta.

Rochmayani, D.S., (2008). Faktor-faktor yang Berhubungan dengan Kebiasaan Merokok Remaja (Studi di Kelurahan Ngaliyan, Kota Semarang Tahun 2007). Jurnal KEMAS, 3(2):126-138.

Sunanto, J., Takeuchi, K., \& Nakata, H., (2005). Pengantar Penelitian dengan Subjek Tunggal, CRICED, University of Tsukuba.

Syafie, R., (2009). Stop smoking: studi kualitatif terhadap pengalaman mantan pecandu rokok dalam menghentikan kebiasaannya. Laporan penelitian, Semarang: Universitas Diponegoro.

Thomas, W., \& Suci, E.S.T., (2010). Merubah perilaku merokok dengan subliminal conditioning. sebuah penelitian eksperi-mental. Jurnal Psikologi Indonesia. VII(1):65-75.

Tobacco Central Support Center (TCSC), (2013). Atlas Tembakau Indonesia. Jakarta: TCSC-Ikatan Ahli Kesehatan Masyarakat Indonesia.

Uthaq, R., \& Kumolohadi, R.A.R., (2008). Hubungan antara kontrol diri dengan perilaku merokok pada siswa-siswi SMAN 1 Parakan, Naskah Publikasi, 3-22. Diunduh dari http:///psychology. uii.ac.id, tanggal 24 Agustus Diunduh dari 2016.

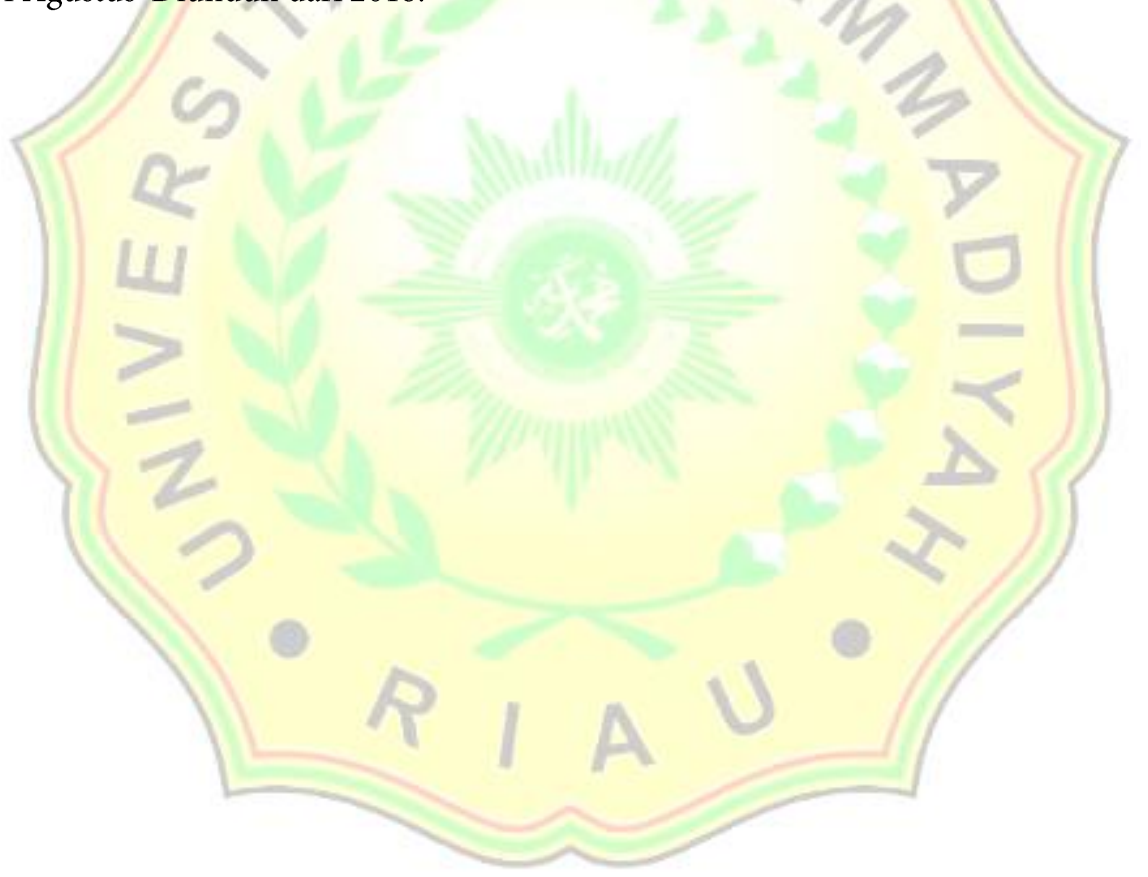

